\title{
HAMBATAN PEMBELAJARAN DARING DALAM MEMBANGUN KARAKTER SISWA SEKOLAH DASAR DI TENGAH PANDEMI
}

\author{
Hanum Aulia Azzahra \\ Universitas Negeri Malang Jawa Tengah, Indonesia \\ Email: hanumauliaazzahra12@gmail.com
}

Received: 2020-02-15; Accepted: 2020-03-05; Published: 2020-03-15

\begin{abstract}
Abstrak
Pandemi Covid-19 mengharuskan sekolah melakukan pembelajaran daring di rumah sesuai dengan arahan Mendikbud melalui Surat Edaran No. 4 Tahun 2020. Penelitian ini bertujuan untuk mengetahui hambatan serta bagaimana membangun karakter siswa melalui pembelajaran daring. Penelitian ini menggunakan metode library research dengan teknik pengumpulan data dengan cara studi kepustakaan atau menelusuri sumber yang relevan dengan penelitian. Temuan dari studi ini adalah hambatan yang dialami oleh siswa, guru, dan orang tua dalam pembelajaran daring
\end{abstract}

Kata Kunci: Pandemi Covid-19; pembelajaran daring; pendidikan karakter

\begin{abstract}
The Covid-19 pandemic requires schools to conduct online learning at home by the direction of the Minister of Education and Culture through Circular No. 4 of 2020. This study aims to determine obstacles and how to build student character through online learning. This study uses a library research method with data collection techniques using literature study or tracing sources relevant to the research. The findings of this study are the obstacles experienced by students, teachers, and parents in online learning.
\end{abstract}

Keywords : The Covid-19; Online Learning; Character Buliding

\section{PENDAHULUAN}

Indonesia sedang mengalami musibah sejak Maret 2020, Covid-19 yang awalnya hanya menyerang beberapa jiwa hingga menjadi jutaan jiwa telah mengubah status indonesia menjadi darurat hingga Presiden Joko Widodo mengeluarkan Keputusan Presiden Republik Indonesia Nomor 12 Tahun 2020 tentang Penetapan sebagai Bencana Nasional dan menetapkan Covid-19 sebagai pandemi. Lambat laun, kebijakan yang ada mengalami perubahan atau hanya sekedar menyesuaikan dengan keadaan yang darurat. Mulai dari aktivitas masyarakat, perekonomian hingga pendidikan. Dalam dunia pendidikan, banyak sekali kebijakan yang dikeluarkan agar pendidikan tetap berjalan namun dengan tetap mencegah penyebaran Covid-19. Dari dikeluarkannya Surat Edaran Nomor 2 Tahun 2020 hingga diberlakukan pembelajaran daring.

Menurut (Suriadi, Firman, \& Ahmad, 2021) Pendidikan adalah proses pembelajaran yang bertujuan untuk mengembangkan bakat pada diri anak, baik itu bersifat kepribadian, kecerdasan, spritual dan kegamaan. Pembelajaran merupakan bagian terpenting dari pendidikan. Menurut UU No. 20 Tahun 2003 Tentang Sisdiknas Pasal 1 Ayat 20 Pembelajaran adalah proses interaksi peserta didik dengan pendidik dan sumber belajar pada suatu lingkungan belajar. Sejalan dengan hal tersebut, pembelajaran merupakan proses yang sistematis dan sistemik yang bersifat interaktif dan komunikatif antara pendidik dengan siswa, sumber belajar dan lingkungan untuk menciptakan situasi dan kondisi yang 
memungkinkan terjadinya tindakan belajar (Arifin, 2010). Pembelajaran pada biasanya berlangsung secara tatap muka langsung, namun pandemi Covid-19 telah mengubah kebijakan menjadi pembelajaran dilakukan secara daring (dalam jaringan) sesuai dengan Surat Edaran Nomor 4 Tahun 2020 yang dikeluarkan oleh Menteri Pendidikan Nadiem Anwar Makarim.

Pembelajaran pada biasanya menggunakan Kurikulum 2013 yang tidak hanya menekankan aspek kognitif saja namun membangun karakter siswa. Hal tersebut telah tertuang pada Permendikbud No. 69 Tahun 2013 Tentang Kerangka Dasar Dan Struktur Kurikulum Sekolah Menengah bahwa tujuan Kurikulum 2013 adalah mempersiapkan manusia Indonesia agar memiliki kemampuan hidup sebagai pribadi dan warga Negara yang beriman, produktif, kreatif, inovatif, dan afektif serta mampu berkontribusi pada kehidupan bermasyarakat, berbangsa,bernegara, dan peradaban dunia. Namun pada pembelajaran daring, ditetapkan Kurikulum Darurat untuk menyesuaikan dengan kondisi yang ada sebagai pedoman pelaksanaan pembelajaran. Menteri Nadiem Makarim memaparkan bahwa kurikulum yang ada telah dirombak ulang yaitu kegiatan pembelajaran dilakukan hanya tiga bulan. Artinya, Kurikulum 2013 telah dipadatkan dan harus diselesaikan dalam waktu yang telah ditentukan. Dengan begitu pembelajaran daring memiliki tantangan yang besar selain menyelesaikan dengan tepat waktu namun bagaimana membangun karakter siswa melalu pembelajaran yang hanya menggunakan teknologi canggih seperti Laptop dan Handphone tanpa bertatap muka secara langsung.

Berdasarkan uraian tersebut, maka tujuan penelitian ini yaitu untuk mengetahui bagaimana hambatan dalam membangun karakter siswa sekolah dasar melalui pembelajaran daring.

\section{METODE PENELITIAN}

Studi ini menggunakan metode library research atau studi pustaka. Metode studi pustaka adalah metode yang sumber data diperoleh dari berbagai literatur, seperti perpustakaan dan google scholar dalam bentuk buku, jurnal, majalah, dokumen dan sebagainya. Dalam menganalisa data penelitian ini, digunakan teknik analisis data yang berupa pengumpulan data, reduksi data, penyajian data dan kesimpulan serta verifikasi.

\section{HASIL PENELITIAN DAN PEMBAHASAN}

Proses pembelajaran di sekolah adalah alat kebijakan publik yang merupakan upaya dalam meningkatkan pengetahuan dan skill belajar siswa (Sari, Tusyantari, \& Suswandari, 2021). Namun pandemi Covid-19 yang melanda Indonesia memberikan dampak besar bagi pendidikan. Bagaimana tidak berpengaruh, awal penyebaran Covid-19 semua sekolah diliburkan oleh pemerintah selama 14 hari untuk mencegah penularan Covid-19 di lingkungan sekolah sesuai dengan arahan Mendikbud Nadiem Makarim melalui Surat Edaran No. 3 Tahun 2020 (Projo, 2020). Menindaklanjuti hal tersebut, pada tanggal 24 Maret 2020 Menteri Pendidikan dan Kebudayaan Republik Indonesia menerbitkan SE No. 4 Tahun 2020 Tentang Pelaksanaan Pendidikan dalam Masa Darurat Covid-19 bahwa proses belajar dilakukan dari rumah melalui pembelajaran jarak jauh/dalam jaringan (daring) untuk memberikan pengalaman belajar yang bermakna bagi siswa (Kementrian Pendidikan Dan Kebudayaan`, 2020)

Pelaksanaan pembelajaran daring dilakukan sesuai dengan kemampuan tiap masingmasing sekolah dengan memanfaatkan teknologi digital seperti $\mathrm{Hp}$ dan Laptop melalui aplikasi rumah belajar, whatsapp group, video conference, zoom, google classroom, google

Hanum Aulia Azzahra / Hambatan Pembelajaran Daring Dalam Membangun Karakter Siswa Sekolah Dasar Di Tengah Pandemi 
meet dan lain sebagainya (Dewi, 2020). Dikutip dari laman resmi Kemdikbud, pembelajaran daring difokuskan untuk meningkatkan pemahaman siswa mengenai Covid-19. Aktivitas pembelajaran dapat bervariasi antar siswa, sesuai dengan minat dan kondisi masing-masing yang termasuk dalam hal kesenjangan akses/fasilitas belajar di rumah. Meskipun pembelajaran dilakukan di rumah masing-masing, guru tetap melaksanakan tugasnya sebagai pembimbing dan mengajak siswa berinteraksi serta berkomunikasi bukan hanya memberikan tugas saja (Kemdikbud, 2014)

Dalam pelaksanaan pembelajaran daring, siswa harus membiasakan diri belajar di rumah tanpa bertemu dengan teman ataupun guru. Hal tersebut dapat berakibat pada psikis siswa. Siswa dapat mengalami perubahan psikologis akibat di rumah terus seperti a) kurangnya keefektifan belajar, b) kurangnya interaksi sosial dengan teman, c) kelambanan perkembangan, kecemasan tinggi dan d) kekebalan tubuh melemah (Mahmudah, 2020). Hal demikian terjadi karena siswa tidak berinteraksi dengan lingkungannya dan harus membiasakan diri dengan lingkungan baru.

Tidak hanya psikis saja sebagai akibat dari pembelajaran daring, namun mempengaruhi karakter siswa juga. Berdasarkan hasil penelitian (Suriadi et al., 2021) peneliti menyimpulkan beberapa tindakan atau karakter siswa yang dipengaruhi oleh pembelajaran daring.

Siswa menjadi tidak bertanggungjawab. Pembelajaran daring dilaksanakan serba online dan jauh dari pengawasan guru secara langsung. Hal tersebut menjadikan siswa terbiasa menunda tugas hingga mengabaikan dan malas mengerjakan tugas dikarenakan merasa tidak ada yang mengawasinya. Siswa menjadi bingung hingga stress. Dikarenakan pembelajaran daring adalah hal yang pertama kali dilakukan tidak seperti biasanya dan tidak diawasi oleh guru, menyebabkan siswa kehilangan minat baca hingga mengabaikan belajar dan tertarik pada game yang ada di Handphone.

Siswa tidak terkontrol. Siswa yang memiliki orang tua yang sibuk menjadi lebih sulit diatur karena tidak diawasi langsung oleh guru serta didampingi oleh orang tua sehingga berbuat semaunya. Pembelajaran daring dalam memanfaatkan teknologi bukan tidak memiliki masalah, namun ada beberapa faktor yang menjadi kendala dalam terlaksananya pembelajaran yaitu

a Keterbatasan penguasaan teknologi informasi oleh guru dan siswa.

b Sarana dan prasarana yang kurang memadai.

c Akses internet yang terbatas.

d Kurang siapnya penyediaan anggaran (Aji, 2020)

Tidak hanya hanya itu, terdapat beberapa hambatan juga dalam membangun karakter siswa melalui pembelajaran daring yaitu sebagai berikut. Siswa belum terbiasa dengan pembelajaran daring. Sebab mereka terbiasa dengan sistem belajar tatap muka secara langsung dengan diawasi serta dibimbing langsung oleh guru.

Siswa mengalami perubahan psikis sebagai akibat dari pembiasaan pembelajaran daring. Siswa hanya berada di rumah dari hari ke hari tanpa bertemu teman ataupun guru. Orang tua kurang mengawasi dan membimbing anaknya. Orang tua sangat berperan penting dalam pembelajaran daring, sebab orang tua merupakan orang yang sering bertemu dengan siswa tersebut. Orang tua lebih mudah dalam membimbing dan mengawasi anak belajar di rumah. Oleh karena itu, siswa perlu mendapat perhatian lebih dan bimbingan dari orang tua ketika melakukan pembelajaran daring ataupun mengerjakan tugas (Shereen, Khan, Kazmi, Bashir, \& Siddique, 2020).

Guru kurang kreatif dan peduli. Guru yang cara mengajarnya tidak bisa menyesuaikan dengan kondisi yang ada akan membuat siswa merasa malas dan kehilangan motivasi 
belajar. Tidak hanya itu, apabila tugas yang diberikan terlalu banyak tanpa memikirkan kemampuan siswa maka akan membuat siswa stress dan semakin malas mengikuti pembelajaran.

Guru memberikan penugasan-penugasan praktik baik (good habit) untuk dilakukan peserta didik dalam pengawasan orang tua. Misalnya, membuat buku agenda harian ibadah dan karakter. Peserta didik ditugaskan untuk mendirikan shalat fardhu berjamaah, shalat sunnat (rawatib, dhuha, qiyamul lail), tilawah Alquran, dan sebagianya, sebagai penanaman karakter religius dan sikap spiritual. Sementara sikap sosial bisa ditugaskan dengan sedekah/infaq harian, membantu orang tua: membersihkan rumah, membersihkan tempat tidur, dan sebagainya (Suastika \& Yasa, 2017). Tidak hanya dari pihak guru saja, namun orang tua berperan penting dalam membangun karakter siswa yaitu dengan mengawasi dan membimbing anaknya. Orang tua harus bisa menyesuaikan diri dan mampu menjadi mentor bagi anaknya (Siahaan \& Agustini, 2021)

\section{KESIMPULAN}

Pembelajaran daring merupakan solusi terbaik yang harus dilakukan agar proses pembelajaran tetap berjalan walaupun di masa pandemi. Pembelajaran daring mengharuskan semua warga sekolah terutama guru dan siswa menggunakan serta mempelajari teknologi yang ada agar menunjang berlangsungnya pembelajaran. Dalam pelaksanaan pembelajaran daring tidak selalu berjalan lancar, ada beberapa hambatan baik dari fasilitas maupun karakter siswa. Tidak semua siswa memiliki handphone ataupun laptop hingga perubahan psikis yang terjadi pada diri siswa.

Untuk mengatasi hambatan tersebut diperlukan peran dari beberapa aspek yaitu pemerintah memberikan bantuan berupa subsidi kuota agar berkurang beban orang tua dalam membiayai proses pembelajaran daring, guru seharusnya memberikan pekerjaan kepada siswa sesuai dengan kemampuannya serta selalu mengawasi, membimbing, berkomunikasi serta berkontribusi terhadap tugas siswa. Orang tua pun sangat berperan penting sebab orang tua sering bertemu dengan anaknya, orang tua harus selalu membimbing dan menjadi mentor serta mengawasi anaknya.

\section{DAFTAR PUSTAKA}

Aji, Rizqon Halal Syah. (2020). Dampak COVID-19 pada pendidikan di indonesia: Sekolah, keterampilan, dan proses pembelajaran. Salam: Jurnal Sosial Dan Budaya Syar-i.(7), 5, 395-402.

Arifin, Syamsul. (2010). Memahami KBK_SCL dan implementasinya. P3AI-ITS, Diunduh Dari Http://Www. Vilila. Com/2010/10/Memahami-Kbk-Scl-Dan-Implementasinya. Html.

Dewi, Wahyu Aji Fatma. (2020). Dampak Covid-19 terhadap implementasi pembelajaran daring di Sekolah Dasar. Edukatif: Jurnal Ilmu Pendidikan, 2(1), 55-61.

Kemdikbud. (2014). konsep dan implementasi kurikulum 2013. In KEMENTERIAN PENDIDIKAN DAN KEBUDAYAAN. Retrieved from https://www.kemdikbud.go.id/kemdikbud/dokumen/Paparan/Paparan Wamendik.pdf

kementrian pendidikan dan kebudayaan`. (2020). belajar dari rumah melaluli pembelajaran 
jarak jauh di SMA (1st ed.; MA Hastuti Mustikaningsih, Ed.). Retrieved from http://repositori.kemdikbud.go.id/20548/1/Belajar dari Rumah melalui Pembelajaran Jarak Jauh di SMA.pdf

Projo, Wahyu Adityo. (2020). Pedoman Pencegahan Penularan Virus Corona dari Nadiem Makarim untuk Siswa dan Mahasiswa. Retrieved from https://www.kompas.com/edu/read/2020/03/10/194616271/pedoman-pencegahanpenularan-virus-corona-dari-nadiem-makarim-untuk-siswa

Sari, Ria Puspita, Tusyantari, Nabila Bunnanditya, \& Suswandari, Meidawati. (2021). Dampak Pembelajaran Daring Bagi Siswa Sekolah Dasar Selama Covid-19. Prima Magistra: Jurnal Ilmiah Kependidikan, 2(1), 9-15.

Shereen, Muhammad Adnan, Khan, Suliman, Kazmi, Abeer, Bashir, Nadia, \& Siddique, Rabeea. (2020). COVID-19 infection: Origin, transmission, and characteristics of human coronaviruses. Journal of Advanced Research, 24, 91.

Siahaan, Sabda Dian Nurani, \& Agustini, Fauzia. (2021). Analisis Kepuasan Pelanggan Dengan Metode Customer Satisfaction Index (CSI)(Studi Kasus Pada BNI UNIMED). Journal of Business and Economics Research (JBE), 2(1), 13-19.

Suastika, I. Gede Yoga, \& Yasa, I. Nyoman Mahaendra. (2017). Pengaruh Jumlah Kunjungan Wisatawan, Lama Tinggal Wisatawan, dan Tingkat Hunian Hotel terhadap Pendapatan Asli Daerah dan Kesejahteraan Masyarakat pada Kabupaten/Kota di Provinsi Bali. E-Jurnal Ekonomi Pembangunan Universitas Udayana, 6(7), 1338.

Suriadi, Harri Jumarto, Firman, Firman, \& Ahmad, Riska. (2021). Analisis Problema Pembelajaran Daring Terhadap Pendidikan Karakter Peserta Didik. Edukatif: Jurnal IImu Pendidikan, 3(1), 165-173.

(C) 2020 by the authors. Submitted for possible open access publication under the terms and conditions of the Creative Commons Attribution (CC BY $\mathrm{SA}$ ) license (https://creativecommons.org/licenses/by-sa/4.0/) 